\title{
The Bodies of the Condemned: The Return of the Body as the Object of State Power
}

\author{
Kenzo E. Okazaki \\ Middlebury College
}

Note: This paper was composed in advance of the events of the summer of 2020 which were largely motivated by the murder of George Floyd. In light of the ever-present police violence against Black Americans, this paper is dedicated to those who have lost their lives at the hands of police and hopes to offer a modest contribution toward scholarship which aims to confront racism in all of its forms. The author hopes that this small work will help to meet our academic responsibility to reject racism.

"Where there is power, there is resistance.",

- Michel Foucault

In 1757 Robert-François Damiens was brought before the people of Paris to make the amende honorable for attempted regicide. Damiens was a domestic servant born in Tieuloy who, by all accounts, was a "fairly unremarkable man."2 The motivation for his crime remains unclear, but records state that on 5 January 1757, Damiens stabbed King Louis XV as he returned to Versailles. ${ }^{3}$ Upon the scaffold which awaited him, Damiens faced a most gruesome execution. The amende honorable was a ritual of public humiliation as punishment for a crime with roots in Roman antiquity. ${ }^{4}$ The practice persisted through the Middle Ages, and Damiens was to be the

\footnotetext{
${ }^{1}$ Michel Foucault, The History of Sexuality, vol. 1, The Will to Knowledge (New York: Random House, 1990$), 95$.

2 Jayne Mooney, “A Tale of Two Regicides," European Journal of Criminology 11, no. 2 (2014): 232; Pièces Originales et Procédures Du Procès Fait à Robert-François Damiens, Tant En La Prévôté de l'Hôtel Qu'en La Cour de Parlement (Paris: Pierre-Guillaume Simon, 1757), v.

${ }^{3}$ Pièces Originales et Procédures Du Procès Fait à Robert-François Damiens, xx ; see also : Mooney, "A Tale of Two Regicides," 234.

${ }^{4}$ Jean-Marie Moeglin, "Pénitence Publique et Amende Honorable au Moyen Age,” Revue Historique 298, fasc. 2 (1997): 225.
} 
victim of among the most gratuitously violent of its iterations. ${ }^{5}$ Foucault describes how Damiens was to have the flesh "torn from his breasts, arms, thighs and calves with red-hot pincers" and a potion of molten lead and oil poured over the wounds before being drawn and quartered. ${ }^{6}$ In 2016, Philando Castile was driving with his girlfriend and daughter when he was pulled over by police. He informed the officer who had stopped him that he was carrying a firearm, and the officer instructed him not to reach for it. The officer then came under the impression that Castile was, in fact, reaching for the weapon and discharged seven rounds into the vehicle striking Castile five times. As the confusion subsided, Castile's girlfriend told the officer that he was reaching for his wallet, as the officer had requested his driver's license. ${ }^{7}$ To interpolate Foucault's own words of comparison, each execution does not punish the same crime, "but they each define a certain penal style." 8

The events are separated by hundreds of years, yet each style of punishment is defined by its focus on the body, its domination, and its destruction. Foucault's analysis, however, held that a few decades after the execution of Damiens, "the body as the major target of penal repression disappeared." Panoptic practices replaced the old exercise of power in the form of outright sovereignty over individual bodies and turned its focus to the social body as a whole. ${ }^{10}$ The panoptic exercise of power requires techniques which entail "total and detailed surveillance."11 Such surveillance has certainly proliferated into contemporary policing and state control in such iterations as the National Security Agency's PRISM and UPSTREAM programs which collect personal data from such services as Gmail, Outlook, SkyDrive, Facebook, Amazon, and Netflix. ${ }^{12}$ These programs characterize one form of contemporary police power. Nikhil Singh, however, indicates that policing today manifests itself as "a force that reaffirms rightlessness as a shadow law written with violence upon the body." ${ }^{13}$ What then of this return to the body? The inherent criminalization of non-white bodies in the United States, especially Black bodies, creates a target group upon which state power must be projected. Though Damiens was sentenced to death and Castille was not, analyzing the construction of policing in the United States reveals that, in a way, a sentence has been conferred on Black Americans. Through the

\footnotetext{
${ }^{5}$ Moeglin, "Pénitence Publique et Amende Honorable au Moyen Age," 225.

${ }^{6}$ Pièces Originales et Procédures du Procès Fait à Robert-François Damiens, III (1757): 372-374, quoted in Michel Foucault, Discipline \& Punish (New York: Random House, 1995), 3.

${ }^{7}$ Gale Biography in Context, "Philando Castile," accessed January 26, 2019, http://link.galegroup.com/apps/doc/K1650010788/BIC?u=vol_m58c\&sid=BIC\&xid=6d01e27d

${ }^{8}$ Michel Foucault, Discipline \& Punish (New York: Random House, 1995), 7.

${ }^{9}$ Foucault, Discipline \& Punish, 8.

${ }^{10}$ Foucault's analysis here descends from Jeremy Bentham's Panopticon. Bentham envisioned the Panopticon as a prison where guards could see into each cell, but the prisoners could not see the guards in the tower or tell when they were being observed. This surveillance was intended to produce good behavior. See: Foucault, Discipline \& Punish, 197.

${ }^{11}$ Foucault, Discipline \& Punish, 220.

${ }^{12}$ Bernard E. Harcourt, The Counterrevolution (New York: Basic Books, 2018), 153.

${ }^{13}$ Nikhil P. Singh, "Race, War, Police," in Race and America's Long War (Oakland: University of California Press, 2017), 36.
} 
importation of counterinsurgency strategy, policing has redirected the projection of state power to be once again wrought upon the bodies of the condemned.

Due to the history of American slavery and racial discrimination, Black bodies are seen as inherently criminal in the United States. Bryan Stevenson describes how the ideology of white supremacy persists and finds material iteration as "people of color in the United States, particularly young black men, are burdened with a presumption of guilt and dangerousness." 14 The modern association of Blackness with criminality have deep roots in the United States. In The Condemnation of Blackness, Khalil Muhammed describes how since the end of the Civil War "notions about blacks as criminals materialized in national debates about the fundamental racial and cultural differences between African Americans and native-born whites." 15 This discourse continued into the twentieth century which marked "the founding moment for the emergence of an enduring statistical discourse of black dysfunctionality." "This discourse has endured and "binds race to crime today as in the past." ${ }^{17}$ Nowhere is this connection more clearly demonstrated than in the discourse surrounding the murder of Trayvon Martin, an innocent, unarmed Black teenager, by George Zimmerman. Geraldo Rivera, a commentator for Fox News, remarked: "when you see a kid walking down the street, particularly a dark-skinned kid...what do [you] think? What's the instant identification, what's the instant association?"18 Rivera went on to contend that the instant association is with criminals and gangsters and that people will view the person in question as a "menace." 19 Non-white bodies in the United States have thus come to be viewed as inherently criminal, an association which persists to this day.

Genealogical analysis of police practice itself reveals that policing is based on the assumption of the inherent criminality of non-white bodies. To Foucault, genealogy is a method of historical inquiry which is from pure history. Because, in his view, the historian is inclined to reduce events to "the lowest common denominator," a historian's history ignores certain knowledges in order to construct a seemingly necessary progression toward truth. ${ }^{20}$ Genealogical analysis rejects the essential progression toward a necessary end and takes into account "the false appraisals, and the faulty calculations that gave birth to those things which continue to exist and have value for us." 21 Furthermore, insofar as "humanity instills in each of its violences a system of rules and proceeds from domination to domination," the value of this analysis "resides in

\footnotetext{
${ }^{14}$ Bryan Stevenson, “A Presumption of Guilt," in Policing the Black Man, ed. Angela J. Davis (New York: Pantheon Books, 2017), 4.

${ }^{15}$ Khalil Gibran Muhammed, The Condemnation of Blackness: Race, Crime, and the Making of Modern Urban America (Cambridge: Harvard University Press, 2010), 4.

${ }^{16}$ Muhammed, The Condemnation of Blackness, 7.

${ }^{17}$ Muhammed, The Condemnation of Blackness, 1.

${ }^{18}$ Katherine Fung, “Geraldo Rivera: Trayvon Martin's 'Hoodie Is As Much Responsible For [His] Death As George Zimmerman' (VIDEO),” Huffington Post, March 23, 2012, 10:22 a.m. EST, https://www.huffingtonpost.com/2012/03/23/geraldo-rivera-trayvon-martin-hoodie_n_1375080.html

${ }^{19}$ Fung, “Geraldo Rivera: Trayvon Martin's 'Hoodie Is As Much Responsible For [His] Death As George Zimmerman' (VIDEO)."

${ }^{20}$ Michel Foucault, "Nietzsche, Genealogy, History," in Aesthetics, Method, and Epistemology, ed. James D. Faubion (New York: The New Press, 1998), 383.

${ }^{21}$ Foucault, "Nietzsche, Genealogy, History," 374.
} 
challenging established practices of remembering and forgetting by excavating subjugated bodies of experiences and memories, bringing to the fore the perspectives that culturally hegemonic practices have foreclosed." 22 Genealogy may reveal how dominant forms of knowledge production have sanitized and constructed practices and institutions as necessary despite their unpalatable legacies which continue to define them.

Police are one institutional feature of governance often assumed to be a constant feature of civil society and necessary in its development. Foucault challenged this view through a genealogical analysis inn his lectures at the College De France. He contends that the uniformed police we see today has not always been necessary and that they do not find origin in the intent to protect individuals in society. Rather, they descend from the concept of police as "the set of intentions and means that ensure that living, better than just living, coexisting will be effectively useful to the constitution and development of the state's forces." 23 The police were not intended to protect citizens, but to maximize the forces of the state. This prerogative licensed the criminalization of non-whiteness in the United States. Singh elaborates upon this investigation describing how non-white people in the early United States were considered "constitutively outside and incapable of participating in civil society." ${ }^{24}$ As police practice is meant to defend civil society, those outside of it and otherwise seen as unproductive and dangerous to the power of the state would be condemned as criminals as "criminality is the name given to a type of violence that threatens the social and civic order." 25 The very state which is under police protection and has been sanitized as providing liberty and freedom for all also warrants genealogical analysis. In American Slavery, American Freedom, Edmund S. Morgan argued that the birth of the United States as a republic founded on liberty and equality was only possible through the knowledge of freedom's Manichean opposite: slavery. Indeed, "racism became an essential, if unacknowledged, ingredient of the republican ideology that enabled Virginians to lead the nation." 26 Morgan concludes his genealogical analysis by wondering if America today is still colonial Virginia writ large. ${ }^{27}$ In a more localized analysis, Robin D.G. Kelley wrote that Blackness is that "against which normality, whiteness, and functionality have been defined."28 As such, it was foundational to constructing modern urban America. ${ }^{29}$ Upon reviewing the genealogy of police practice and that of the United States, it is no surprise that the criminalization of Black bodies persists to this day.

\footnotetext{
${ }^{22}$ Foucault, "Nietzsche, Genealogy, History," 378; José Medina, "Toward a Foucaultian Epistemology of Resistance: Counter-Memory, Epistemic Friction, and Guerrilla Pluralism,” Foucault Studies 1, no. 12 (October 2011): 11.

${ }^{23}$ Michel Foucault, "29 March 1978," in Security, Territory, Population, ed. Michel Senellart (Basingstoke: Palgrave Macmillan, 2007), 327.

${ }^{24}$ Singh, "Race, War, Police," 43.

${ }^{25}$ Singh, "Race, War, Police," 73.

${ }^{26}$ Edmund S. Morgan, American Slavery, American Freedom (New York: W.W. Norton \& Company, 1975 ), 386.

${ }^{27}$ Morgan, American Slavery, 387.

${ }^{28}$ Robin D.G. Kelley, Yo' Mama's Disfunktional! Fighting the Culture Wars in Urban America (Boston: Beacon Press, 1997), 3.

${ }^{29}$ Muhammed, The Condemnation of Blackness, 7.
} 
How, then, has this inherent criminalization come to be focused on Black bodies? It was the influence of French counterinsurgency strategy on modern American police forces which revived a dated punitive regime whose focus and object was the body. The writings of the central thinkers who produced this strategy, Roger Trinquier, David Galula, and Paul Aussaresses, were imported and annexed by the military and heavily influence contemporary police forces. In Counterinsurgency Warfare: Theory and Practice, David Gaula asserted that victory in modern warfare relies on identifying an active minority of a population who is organized in resistance. ${ }^{30}$ More than mere identification, theorists of counterinsurgency strategy also emphasized punishment. Trinquier, in Modern Warfare: A French View of Counterinsurgency, emphasized the necessity of "the complete destruction" of this minority. ${ }^{31}$ Paul Ausseresses defended the use of summary execution as he argued in his memoir, The Battle of the Casbah, that "by asking the military to reestablish law and order inside the city of Algiers, the civilian authorities had implicitly approved of having summary executions." 32 In The Counterrevolution, Bernard Harcourt delineates how "French counterinsurgency theory made [its] way across the Atlantic rapidly." "33 This exchange began as early as the 1950s when Trinquier "was invited to visit US counterinsurgency training facilities in Korea and Japan, and was enlisted to train American commandos." "34 Aussaresses also "traveled to the United States...to teach counterinsurgency practices to elite American Special Forces." ${ }^{35}$ Galula became an influential figure in the United States as he "lectured at Fort Bragg, spent six months at the Armed Forces Staff College at Norfolk, Virginia, and spent two years at Harvard University's Center for International Affairs as a research associate." 36 Beyond these roles, Galula's work became extremely popular among military experts. This influence is today evident in the work of General David Petraeus. Harcourt describes how Petraeus's field manual "reads like an ode to early French counterinsurgency strategy" and that "the influence of Galula is everywhere evident." ${ }^{37}$ In short, Harcourt finds that "general David Petraeus picked up right where Galula...left off." 38

Galula's impact on the military has migrated into police practices through the militarization of police forces. Today, police officers are becoming more and more like the military in the way they operate, think, and equip themselves. ${ }^{39}$ Radley Balko emphasizes this trend in The Rise of The Warrior Cop as "declaring war on abstractions like crime, drug use, and terrorism" have created policy which "have made those war metaphors increasingly real." 40 The

\footnotetext{
${ }^{30}$ Harcourt, The Counterrevolution, 30.

${ }^{31}$ Roger Trinquier, Modern Warfare: A French View of Counterinsurgency (London: PSI, 2006), 7.

${ }^{32}$ Paul Aussaresses, The Battle of the Casbah (New York: Enigma Books, 2006), 117.

${ }^{33}$ Harcourt, The Counterrevolution, 45.

${ }^{34}$ Harcourt, The Counterrevolution, 45.

${ }^{35}$ Harcourt, The Counterrevolution, 45.

${ }^{36}$ Harcourt, The Counterrevolution, 47.

${ }^{37}$ Harcourt, The Counterrevolution, 32-33.

${ }^{38}$ Harcourt, The Counterrevolution, 30.

${ }^{39}$ Radley Balko, Rise of the Warrior Cop: The Militarization of America's Police Forces (New York: Public Affairs, 2014), 41.

${ }^{40}$ Balko, Rise of the Warrior Cop, 42.
} 
implications of this French connection, however, span beyond mere military strategy. Harcourt explains that counterinsurgency strategy "is a political theory, not simply a military strategy. It is a worldview, a way of dealing with all situations-whether on the field of battle or off it." ${ }^{\prime 41}$ As a military strategy and as a political theory, counterinsurgency has become ingrained in police practice in the United States. Indeed, "a counterinsurgency mindset has begun to dominate ordinary policing" insofar as there is increasingly "an active minority that needs to be identified and eliminated." ${ }^{\prime 2}$ Harcourt describes how such identification has been used with respect to "African Americans in the context of social movements against police killings of unarmed civilians." ${ }^{.43}$ The dominance of counterinsurgency strategy in the United States, however, is apparent in more than Harcourt's analysis of the identification of the active minority.

The importation of a counterinsurgency strategy and mindset in policing has licensed practices which reaffirm the expression of power upon the bodies of those Black citizens considered inherently criminal. Though this claim does not deny that instances of police brutality against Black and non-white people have been endemic in the United States since its inception, it does offer an interpretation of how this practice has been systematized and refined. Harcourt indicates that Black Americans protesting police brutality have been identified as an active minority to be eliminated. ${ }^{44}$ More than simply identification, however, was imported with counterinsurgency strategy. The positioning of non-white citizens as an active minority licenses, recalling Trinquier's words, their "complete destruction." ${ }^{45}$ Indeed, the emphasis placed on punishment in counterinsurgency theory also made its way into contemporary policing. Galula's work demanded that "the rebels' flagrant crimes must be punished immediately, mercilessly, and on the very spot where they took place." ${ }^{46}$ This practice bears a striking similarity to the practices Foucault described of 18th century executions which were "often carried out at the very place where the crime had been committed." ${ }^{47}$ The crime and the body were intertwined by place and the spectacle showed that "the body of the condemned man was once again an essential element in the ceremonial of public punishment." ${ }^{, 48}$ In other words, counterinsurgency strategy held that the body would once again be the place at which power should be focused. There is then no more immediate or direct punishment wrought upon the body then than Aussaresses' practice of summary execution. The case of Philando Castile illustrates the annexation of these practices by police in the United States. As a Black man, Castile was identified as a criminal

\footnotetext{
${ }^{41}$ Harcourt, The Counterrevolution, 31.

${ }^{42}$ Harcourt, The Counterrevolution, 141.

${ }^{43}$ Harcourt, The Counterrevolution, 171.

${ }^{44}$ Harcourt, The Counterrevolution, 141. Though accurate, this conclusion appears limited in light of the assertion that police view all non-white citizens as inherently criminal. Non-white bodies then themselves represent an active minority positioned outside of and in contention with civil society.

${ }^{45}$ Trinquier, Modern Warfare, 7.

${ }^{46}$ David Galula, Pacification in Algeria (Santa Monica: RAND, 2006), 268 quoted in Geoff Demarest, "Let's Take the French Experience Out of US Counterinsurgency Doctrine," Military Review (July/August 2010), 21.

${ }^{47}$ Foucault, Discipline \& Punish, 44.

${ }^{48}$ Foucault, Discipline \& Punish, 43.
} 
which resulted in as many as 49 traffic stops over the course of 13 years. ${ }^{49}$ Eventually, he was shot where he stood, summarily executed for the inescapable criminality which accompanied the color of his skin. He was punished at the very location of his crime: anywhere and everywhere he went.

The United States and its police practices are steeped in a lineage of racism which originated in the identification of certain bodies as detrimental to civil society and thus criminal. The later importation of French counterinsurgency strategy necessitated the complete destruction of criminals and licensed practices to punish them, which refocused the expression of state power upon the body. Understanding the practice of power, its apparatuses, its technologies, and its objects are essential to resistance. Foucault wrote that "just as the network of power relations ends by forming a dense web that passes through apparatuses and institutions...so too the swarm of points of resistance," and "it is doubtless the strategic codification of these points of resistance that makes a revolution possible." 50 As we see a renewed focus on the body, we also see reflections of the past which rendered this practice obsolete. Foucault notes in Discipline \& Punish that the danger of making a public example of the body was "the risk of being rejected by the very people it addressed." 51 This bred a "political fear of the effects of these ambiguous rituals," which resulted in their eventual elimination. ${ }^{52}$ Today, the murder of unarmed non-white people faces the same problem. This is not to say that the summary executions derived from counterinsurgency practice are meant to be the spectacle which Foucault describes. Indeed, Aussaresses describes how his summary executions were secret and "never held in the same spot twice." 53 However, smartphones and social media which have captured incidents of police shootings render these executions public. In 2015, officer Michael Slager was filmed as he shot Walter Scott, an unarmed Black man, in the back as he ran away. The video which was posted online sparked outrage and demands by groups such as Black Lives Matter for civilian oversight of police. ${ }^{54}$ Once again, civilians are called upon to intervene in unjust punishment, just as the people of Avignon stopped the execution of a man who they deemed had suffered too much at the hands of his executioner during the seventeenth century. ${ }^{55} \mathrm{Can}$ such intervention once again eradicate the practice of power on the body? If so, how will power refine its projection? Only by being vigilant of these transitions can appropriate resistance to racist and oppressive state practices be achieved.

\footnotetext{
${ }^{49}$ Sharon LaFraniere and Mitch Smith, "Philando Castile Was Pulled Over 49 Times in 13 Years, Often for Minor Infractions," The New York Times, July 16, 2016, U.S., https://www.nytimes.com/2016/07/17/us/before-philandocastiles-fatal-encounter-a-costly-trail-of-minor-traffic-stops.html

${ }^{50}$ Foucault, The History of Sexuality, vol. 1, The Will to Knowledge, 96.

${ }^{51}$ Foucault, Discipline \& Punish, 63.

${ }^{52}$ Foucault, Discipline \& Punish, 65.

${ }^{53}$ Aussaresses, The Battle of the Casbah, 114.

${ }^{54}$ Liz Fields, "After Walter Scott Killing, Black Lives Matter Movement Calls For Citizen Oversight of Police," Vice News, April 10, 2015, https://news.vice.com/en_us/article/8x7wxa/after-walter-scott-killing-black-lives-mattermovement-calls-for-citizen-oversight-of-police

${ }^{55}$ Foucault, Discipline \& Punish, 64.
} 


\section{Bibliography}

Aussaresses, Paul. The Battle of the Casbah. New York: Enigma Books, 2006.

Balko, Radley. Rise of the Warrior Cop: The Militarization of America's Police Forces. New York: Public Affairs, 2014.

Fields, Liz. "After Walter Scott Killing, Black Lives Matter Movement Calls For Citizen Oversight of Police," Vice News, April 10, 2015, https://news.vice.com/en_us/article/8x7wxa/after-walter-scott-killing-black-lives-mattermovement-calls-for-citizen-oversight-of-police

Foucault, Michel. Discipline \& Punish. New York: Random House, 1995.

Foucault, Michel. "Nietzsche, Genealogy, History." In Aesthetics, Method, and Epistemology. Edited by James D. Faubion, 369-391. New York: The New Press, 1998.

Foucault, Michel. The History of Sexuality, vol. 1, The Will to Knowledge. New York: Random House, 1990.

Foucault, Michel. "29 March 1978.” In Security, Territory, Population. Edited by Michel Senellart, 311-328. Basingstoke: Palgrave Macmillan, 2007.

Fung, Katherine. “Geraldo Rivera: Trayvon Martin's 'Hoodie Is As Much Responsible For [His] Death As George Zimmerman’ (VIDEO).” Huffington Post, March 23, 2012, 10:22 a.m. EST, https://www.huffingtonpost.com/2012/03/23/geraldo-rivera-trayvonmartinhoodie_n_1375080.html

Gale Biography in Context. "Philando Castile." Accessed January 26, 2019, http://link.galegroup.com/apps/doc/K1650010788/BIC?u=vol_m58c\&sid=BIC\&xid=6d1 e27d

Galula, David. Pacification in Algeria. Santa Monica: RAND, 2006.

Harcourt, Bernard E. The Counterrevolution. New York: Basic Books, 2018.

Kelley, Robin D.G. Yo' Mama's Disfunktional! Fighting the Culture Wars in Urban America. Boston: Beacon Press, 1997.

LaFraniere, Sharon and Mitch Smith. "Philando Castile Was Pulled Over 49 Times in 13 Years, Often for Minor Infractions," The New York Times, July 16, 2016, U.S. https://www.nytimes.com/2016/07/17/us/before-philando-castiles-fatal-encounter-acostly-trail-of-minor-traffic-stops.html

Medina, José. "Toward a Foucaultian Epistemology of Resistance: Counter-Memory, Epistemic Friction, and Guerrilla Pluralism." Foucault Studies 1, no. 12 (October 2011): 9-35. 
Moeglin, Jean-Marie. "Pénitence Publique et Amende Honorable au Moyen Age." Revue Historique 298, fasc. 2 (1997): 225-269.

Mooney, Jayne. “A Tale of Two Regicides.” European Journal of Criminology 11, no. 2 (2014): 228-250.

Morgan, Edmund S. American Slavery, American Freedom. New York: W.W. Norton \& Company, 1975.

Muhammed, Khalil G. The Condemnation of Blackness: Race, Crime, and the Making of Modern Urban America. Cambridge: Harvard University Press, 2010.

Pièces Originales et Procédures du Procès Fait à Robert-François Damiens, III. 1757.

Pièces Originales et Procédures Du Procès Fait à Robert-François Damiens, Tant En La Prévôté de l'Hôtel Qu'en La Cour de Parlement. Paris: Pierre-Guillaume Simon, 1757.

Singh, Nikhil P. “Race, War, Police.” In Race and America's Long War, 35-73. Oakland: University of California Press, 2017.

Stevenson, Bryan. "A Presumption of Guilt.” In Policing the Black Man. Edited by Angela J. Davis, 3-30. New York: Pantheon Books, 2017.

Trinquier, Roger. Modern Warfare: A French View of Counterinsurgency. London: PSI, 2006. 